Military Technical College

Kobry El-Kobbah,

Cairo, Egypt

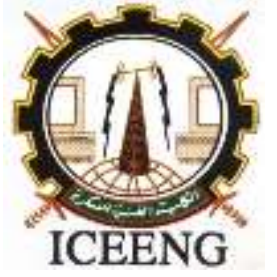

11th International Conference

on Electrical Engineering

ICEENG 2018

\title{
A COMPARATIVE STUDY OF MPPT METHODS FOR PHOTOVOLTAIC SYSTEM CASE STUDY: PV ON ROOF OF UPPER EGYPT BUILDINGS
}

\author{
A. Elmelegi*
}

\begin{abstract}
Recently, depending on PV systems has critical importance to surmounted the energy crunch in Egypt. The Ministry Of Electricity And Renewable Energy found the burden of electricity so tended to save energy in government building and begin the implementation of solar photovoltaic energy stations connected to grid on the roof of all electricity companies buildings. In this paper, a comparison has been made between Perturb and Observe (P\&O) and Incremental Conductance (INC) methods of Maximum Power Point Tracking (MPPT) to achieve the highest efficiency and output power to a solar power station $(40.18 \mathrm{~kW})$ established on the roof of Upper Egypt Electricity Distribution Company (UEEDC) which has been selected as a case study. Moreover, a simulation has been developed under the influence of different solar radiation. All the simulation results has been developed using PSIM software packages.
\end{abstract}

\section{Keywords}

Perturb and Observe (P\&O) and Incremental Conductance (INC) methods, MPPT, PSIM software.

\section{Introduction}

In the current day, there is an increasing demand for energy, leading to a crisis in electric power generation, and The Ministry Of Electricity And Renewable Energy in egypt has tended into to install solar power stations with different powers on top of its surfaces for its initiative in encouraging citizens to use the solar energy and rationalizing of consumption [1]. Diverse renewable sources are used to generate electric power, such as photovoltaic energy, wind power, geothermal energy, biomass energy, ocean energy etc [2]. Photovoltaic energy is a good option for

* Aswan Power Electronic Applications Research Center (APEARC), faculty of engineering, Aswan University. 
generating electrical power, since photovoltaic energy converts direct sunlight into electrical energy through photovoltaic cells units [3]. A group of photovoltaic cells units are connected with each other to form the PV module and connect a group of these modules with each other in series to increase voltage or in parallel to increase the current to form solar PV array station to obtain high output power [4]. There are several factors that affect the output power of PV array station include solar radiation, temperature, the life of the PV module, the tilt angle of solar panel, the shadow and the mismatch of the solar cells and cleaning of the solar panels [5]. To surmounted these issues, it should track the maximum power point of PV module output power and maximum power point tracker is an electronic DC to DC converter that improves the identical between the PV solar arrays and utility grid. In order to preserve the PV modules that works in its maximum power point, various maximum power point tracking methods are proposed like the Perturb and Observe (P\&O) method, Incremental Conductance (INC) method, ripple correlation control method etc, all of these methods were proposed in the literature [6]. The two most prevalent methods are (P\&O) and (INC) methods. The (P\&O) control method is easy and simple but the (P\&O) method is not suitable for fast changing environmental conditions while the (IN C) method is good yield under rapidly changing atmospheric conditions [7]. This paper discuses the follows, section B explains a disaggregated description of a $40.180 \mathrm{~kW}$ PV power plant. Section C explains design of UEEDC converter topology and system description. Section $D$ explains a comprehensive interpretation for the Perturb \& Observe (P\&O) and Incremental Conductance (INC) Maximum Power Point Tracking Methods (MPPT). Section E explains simulation results. The conclusion of the comparison is summarized in section $\mathrm{F}$.

\section{UEEDC PV power station}

PV power station $40.180 \mathrm{~kW}$ is shown in Figure 1. It is designed by using PV mono crystalline TS-S410 module which consists of 96 cells tied in series to generate maximum power $410 \mathrm{~W}$. PV module specifications at Standard Test Condition STC $\left(1000 \mathrm{~W} / \mathrm{m}^{2}, 25^{\circ} \mathrm{C}, \mathrm{AM} 1.5\right)$ are shown in Table 1. The arrays station shown in Fig. 2 , consists of seven parallel strings, each string consists of fourteen modules connected in series. Table 2, Fig. 3(a) and Fig. 3(b) show the average output power and energy generation of PV power station $40.180 \mathrm{~kW}$ through a day in a year. The daily power generation curve within a day (12/10/2017) is shown in Fig. 3(c).

\section{Design of UEEDC converter topology}

PV modules of power station are arranged with DC-DC Buck converter as shown in Fig. 4. A buck converter or voltage regulator is also called a step down regulator since the input voltage is higher than the output voltage [8-9]. The duty ratio of DCDC buck converter is dominated by pulse generated with maximum power point tracking technique. These pulses are created via comparing a carrier wave to control signal. The input voltage of DC-DC buck converter is the output voltage of PV power station $40.180 \mathrm{~kW}$. The relationships between output and input voltage of buck converter are described as equations:-

$\frac{\mathrm{V}_{\mathrm{o}}}{\mathrm{V}_{\mathrm{in}}}=\mathrm{D}=\mathrm{M}(\mathrm{D})$ 
$L=\frac{\left(V_{i n}-V_{o}\right)}{\Delta i_{L}} D T_{S}$

$C=\frac{\Delta i_{L} T_{S}}{8 \Delta V_{o}}$

Table 3 shows the parameters of buck converter which are designed by using equations (1), (2) and (3).

\section{Types of MPPT methods}

\section{a) Perturb and Observe (P\&O) method or algorithm}

In this method ( $\mathrm{P} \& \mathrm{O})$ control algorithm is presented to the arrangement. Due to this disturbance the voltage and power of the PV array are varied. If the PV power is increasing due to the ( $P \& O)$ control algorithm then the disturbance is continued in same track. After the maximum power point is reached then the power at the next step is decreased thus after that case the disturbance becomes in the reverse direction. When the steady state condition is reached to the $P \& O$ vibrating about the maximum power point. Fig. 5. Shows the planning algorithm of Perturb and Observe (P\&O) method. The flow chart of the Perturb and Observe (P\&O) method is shown in Fig. 6. The disaggregated method of perturb and observe (P\&O) is the values of $P V$ array voltage and power at $Z^{\text {th }}$ instantaneous are retained, $Z$ is unit delay. The next step of PV array power is determined at next instantaneous $(Z+1)^{\text {th }}$ of the current and voltage value which are measured from PV array. At $(Z+1)^{\text {th }}$ instantaneous the power and voltage are subtracted with the values from $Z^{\text {th }}$ instantaneous. On the right aspect of Perturb and Observe (P\&O) method, the characteristic where the slope of power is almost constant and voltage is negative $\left(\frac{\Delta p}{\Delta v}<0\right)$ and on the left aspect the slope of power is positive $\left(\frac{\Delta p}{\Delta v}>0\right)$. After determining the values of $[P(Z+1)-P(Z)]$ and $[V(Z+1)-V(Z)]$ the disturbance method determines the increase or decrease of converter duty cycle. Table 4 , shows conclusion of Perturb and Observation (P\&O) MPPT method.

\section{b) Incremental Conductance (INC) method}

The incremental conductance (INC) method is depending on the slope of the PV array power curve which are zero at the maximum power point (MPP), negative on the right, and positive on the left of the MPP

$\frac{\Delta \mathrm{I}}{\Delta \mathrm{V}}=-\frac{\mathrm{I}}{\mathrm{V}} \quad$ at MPP

$\frac{\Delta \mathrm{I}}{\Delta \mathrm{V}}<-\frac{\mathrm{I}}{\mathrm{V}} \quad$ at right of MPP

$\frac{\Delta \mathrm{I}}{\Delta \mathrm{V}}>-\frac{\mathrm{I}}{\mathrm{V}} \quad$ at left of MPP 
Fig. 7, shows tracking the MPP by comparing the instantaneous conductance (I/V) to the incremental conductance $(\Delta \mathrm{l} / \Delta \mathrm{V})$. Once the MPP is achieved, the operation of the PV array is kept at this point otherwise a change in $\Delta \mathrm{I}$ is observed and the change in environmental conditions and the MPP are demonstrated. The incremental conductance (INC) method is decreases or increases the duty cycle to next step track of the new MPP.

\section{Simulation results}

The simulation is carried out with Perturb and Observe (P\&O) and Incremental Conductance (INC) methods on all PV power station array $40.180 \mathrm{~kW}$ under different irradiances $1000 \mathrm{~W} / \mathrm{m}^{2}, 800 \mathrm{~W} / \mathrm{m}^{2}, 500 \mathrm{~W} / \mathrm{m}^{2}$ and $300 \mathrm{~W} / \mathrm{m}^{2}$, the temperature is kept constant at $25^{\circ} \mathrm{C}$. Table 5 , shows the average output power value and efficiency of normal PV power station operation for $1000 \mathrm{~W} / \mathrm{m}^{2}, 800 \mathrm{~W} / \mathrm{m}^{2}, 500 \mathrm{~W} / \mathrm{m}^{2}$ and 300 $\mathrm{W} / \mathrm{m}^{2}$ irradiances with two methods. Fig. 8(a), Fig. 8(b), and Fig. 8(c) show output power at irradiance $1000 \mathrm{~W} / \mathrm{m}^{2}, 800 \mathrm{~W} / \mathrm{m}^{2}, 500 \mathrm{~W} / \mathrm{m}^{2}$ and $300 \mathrm{~W} / \mathrm{m}^{2}$ respectively with Perturb and Observe (P\&O) method. Fig. 9(a), Fig. 9(b), and Fig. 9(c) show output power at irradiance $1000 \mathrm{~W} / \mathrm{m}^{2}, 800 \mathrm{~W} / \mathrm{m}^{2}, 500 \mathrm{~W} / \mathrm{m}^{2}$ and $300 \mathrm{~W} / \mathrm{m}^{2}$ respectively with Incremental Conductance (INC) method.

The efficiency is determined as follows:

$\frac{\mathrm{Ppv}}{\mathrm{P}_{\mathrm{mpp}}} \times 100 \%=\eta \mathrm{mppt}$

where Ppv is the power obtained from the PV power station by using (PSIM) software and Pmpp is the theoretical maximum of PV power station $40.180 \mathrm{~kW}$. The Ppv and Pmpp data are obtained when the irradiation changes with $1000 \mathrm{~W} / \mathrm{m}^{2}, 800 \mathrm{~W} / \mathrm{m}^{2}$, $500 \mathrm{~W} / \mathrm{m}^{2}$ and $300 \mathrm{~W} / \mathrm{m}^{2}$.

\section{Conclusion}

This paper shows the difference between the two most important methods of maximum power point tracking (MPPT) using the PV power station $(40.18 \mathrm{~kW})$ established on the roof of Upper Egypt Electricity Distribution Company (UEEDC) . The results show that the efficiency of incremental conductance (INC) method is higher than the efficiency of perturb and observation (P\&O) method. The MPPT has the highest efficiency and has the maximum output power for the solar power station (40.18 kW) using the incremental conductance (INC) MPPT method.

\section{References}

[1] A. Elmelegi and E.M. Ahmed, "Study of Different PV Systems Configurations Case Study: Aswan Utility Company", 17th International Middle East Power Systems Conference, Mansoura University, Egypt, December 15-17, (2015).

[2] R. Messenger and J. Ventre, "Photovoltaic Systems Engineering", CRC Press, 
pp. 41-51(2000).

[3] J. Perlin, "The Story Of Solar Electricity", Harvard University Press: London, (1999).

[4] F.A. Salem, "Modeling and Simulation issues on Photovoltaic systems for Mechatronics design of solar electric applications", Vol. 2, Issue 8, August (2014).

[5] H. Patel and V. Agarwal, "MATLAB-based modeling to study the effects of partial shading on PV array characteristics", IEEE Transaction on Energy Conversion, Vol. 23, No. 1, pp. 302-310 (2008).

[6] T. Esram, and P.L. Chapman, "Comparison of Photovoltaic Array Maximum PowerPoint Tracking Techniques", IEEE Transactions on Energy Conversion, Vol. 22, No. 2, pp. 439-449 (2007).

[7] I.V. Banu, R. Benigua, M. Istrate, "Comparative Analysis of the Perturb-andObserve and incremental Conductance MPPT Methods", $8^{\text {th }}$ International Symposium On Advanced Topics In Electrical Engineering, pp. 1-4 (2013).

[8] A.P.K. Yadav, S. Thirumaliah and G. Haritha, "Comparison of MPPT Algorithms for DC-DC Converters Based PV Systems" IJAREEIE Vol. 1, Issue 1, July (2012)

[9] U. Srikanth, P.P. Kumar and K.V.V. Prasad, "A COMPREHENSIVE COMPARISON OF MPPT ALGORITHMS WITH DC-DC CONVERTERS FOR SOLAR PV ARRAY", JETIR Vol. 4, Issue 09, September (2017).

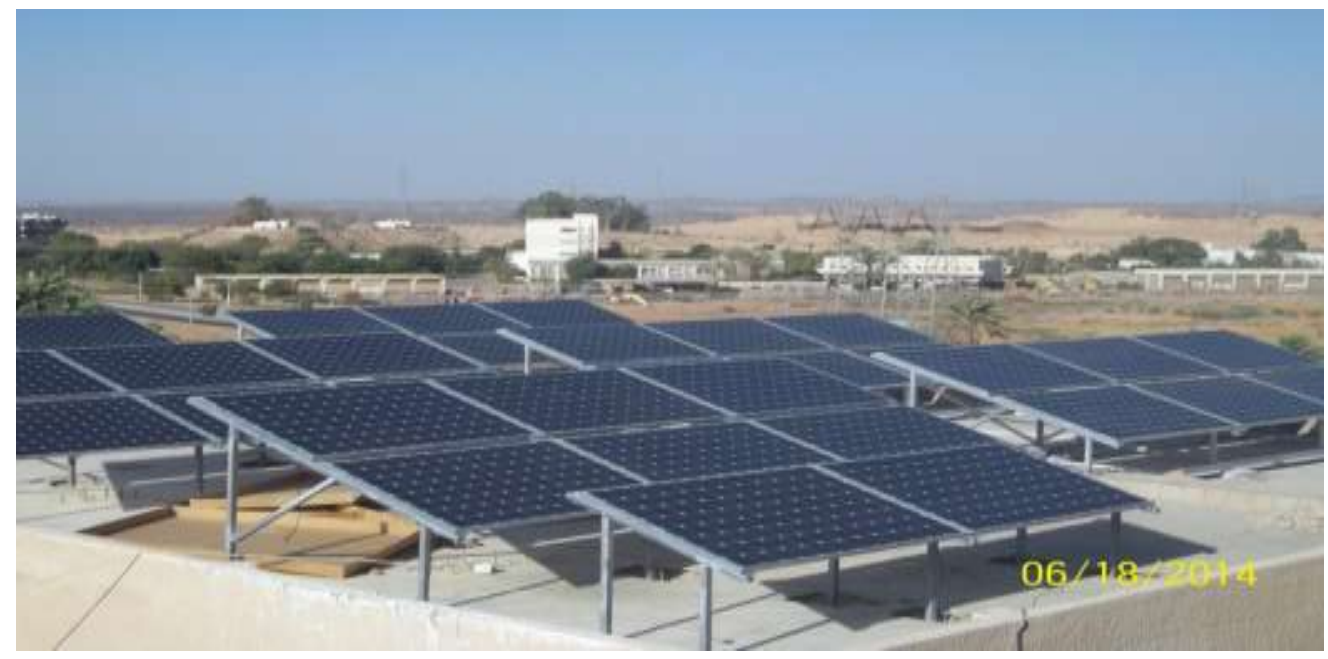

Fig.1. UEEDC PV power station $(40.180 \mathrm{kWp})$ 


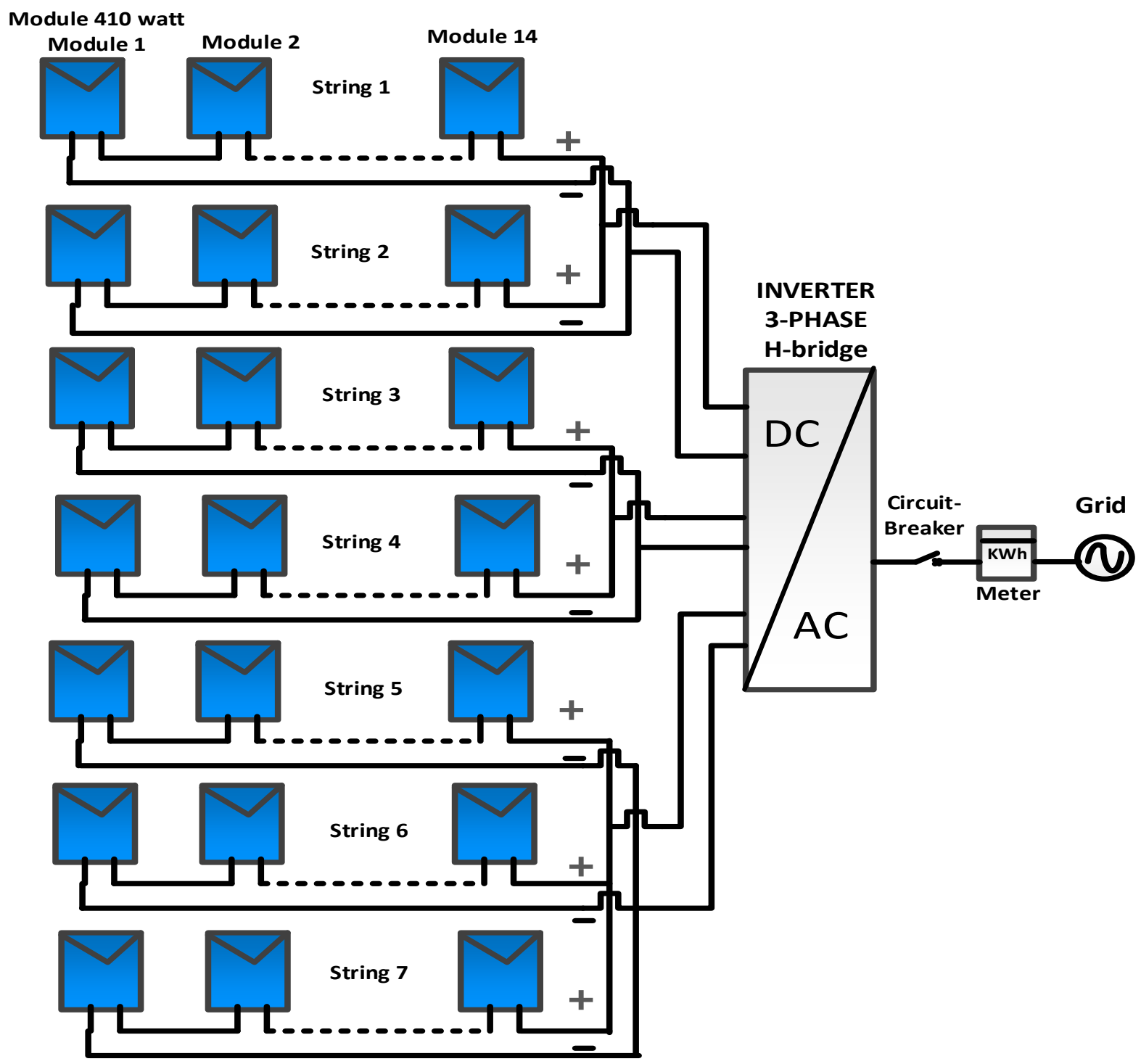

Fig.2. The arrays station configuration

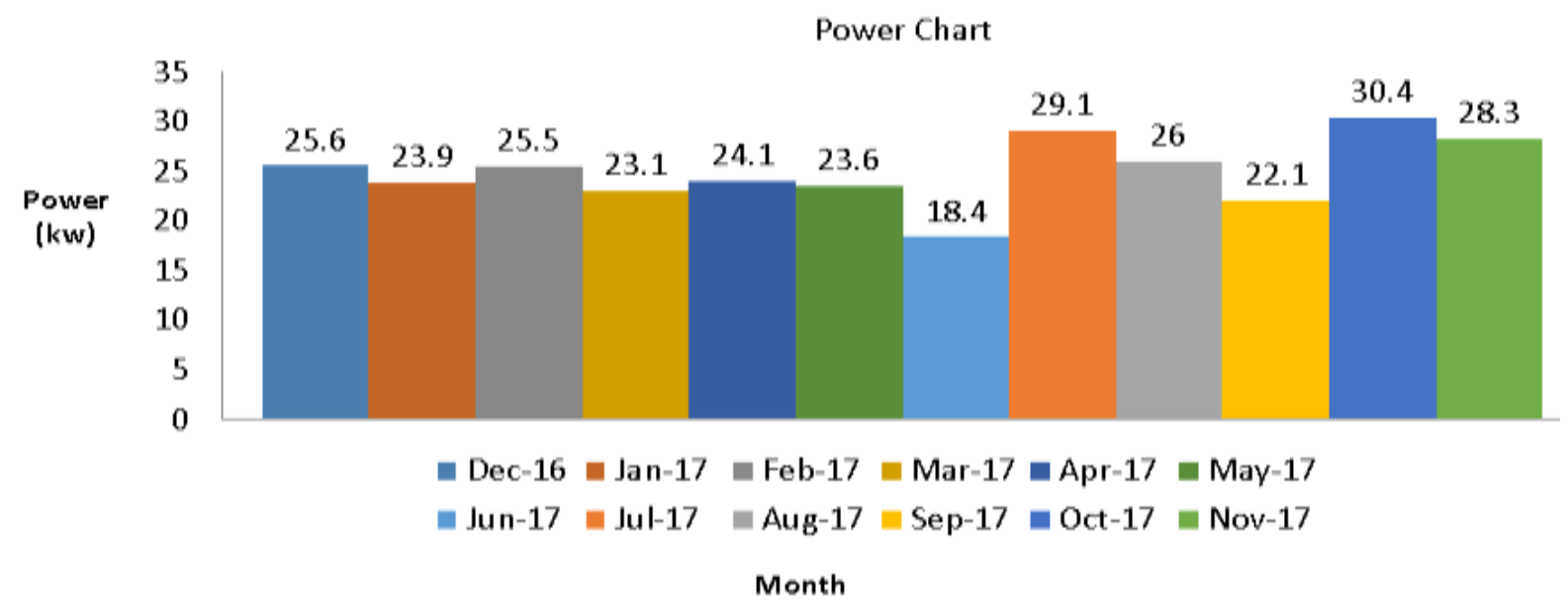

(a) 


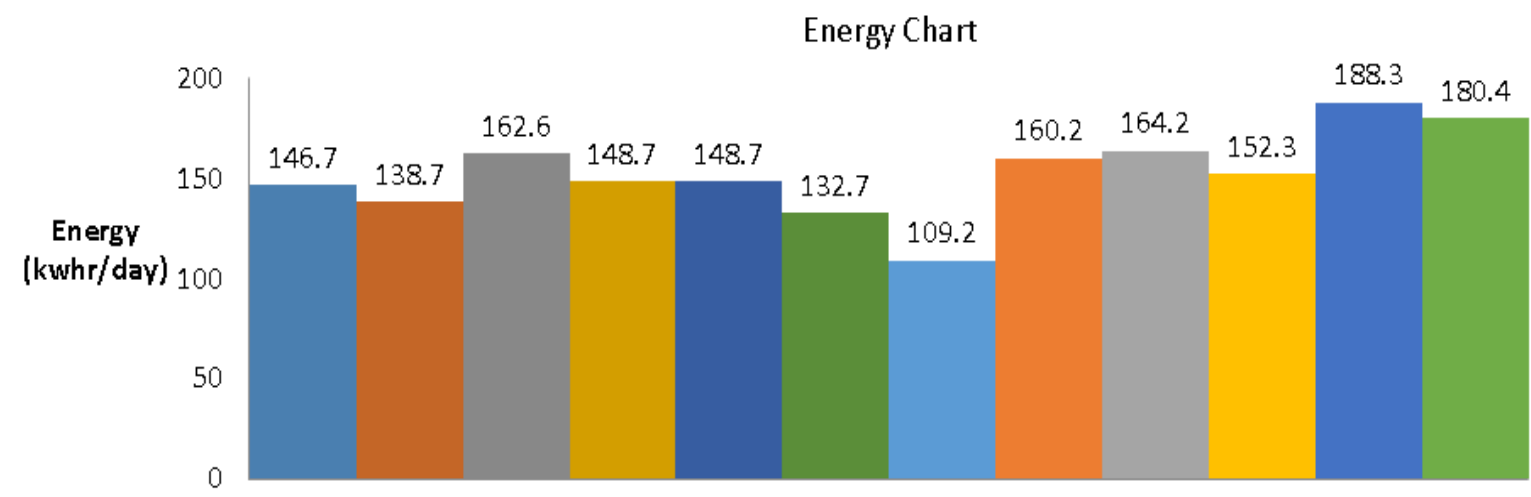

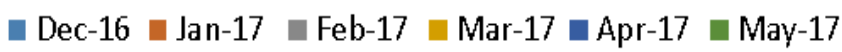

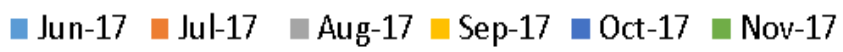

Month

(b)

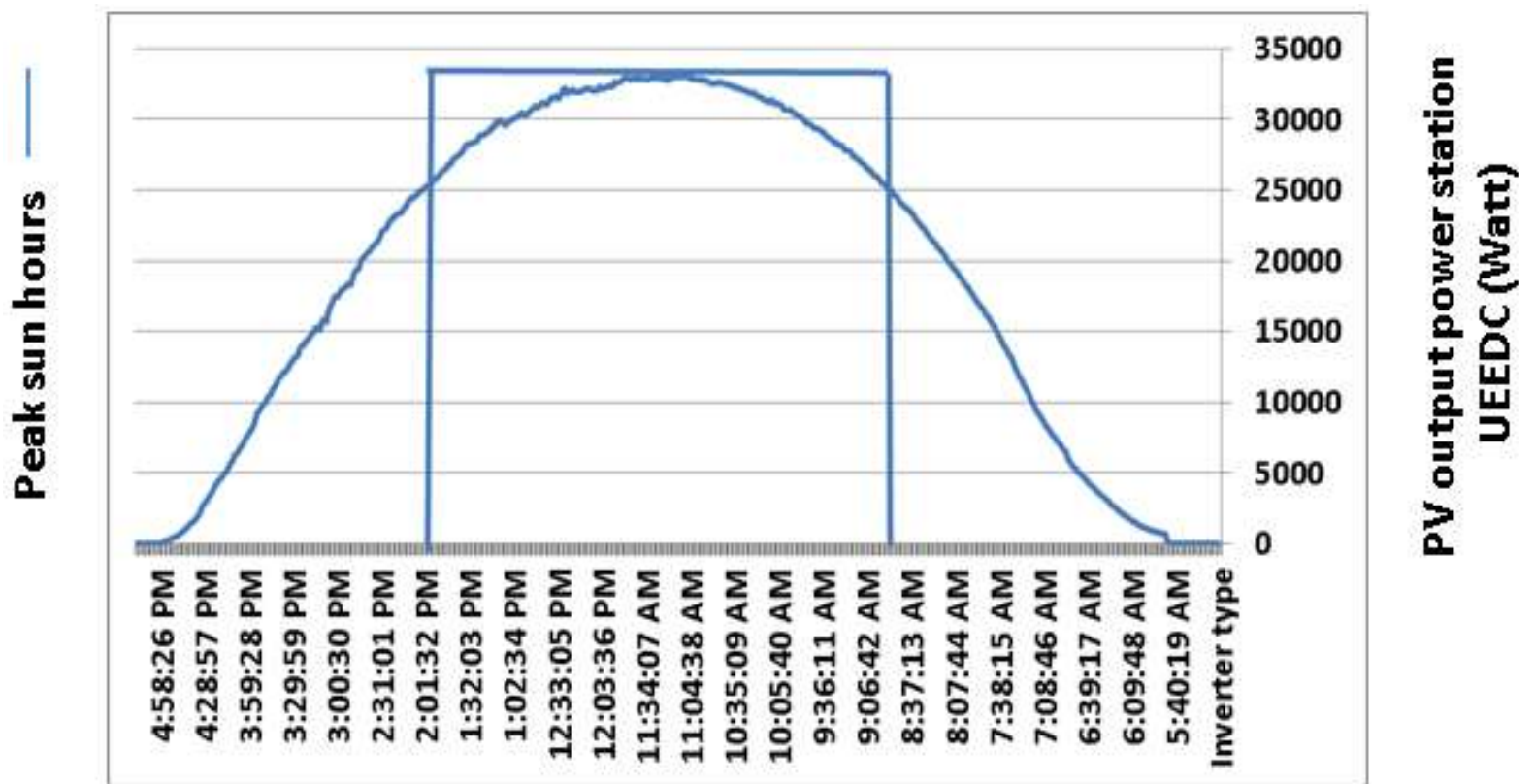

Time (hh:mm:ss)

(C)

Fig.3. Graphical representation of UEEDC output power and energy through one day in a year (a) power production (b) energy production (c) daily power curve 


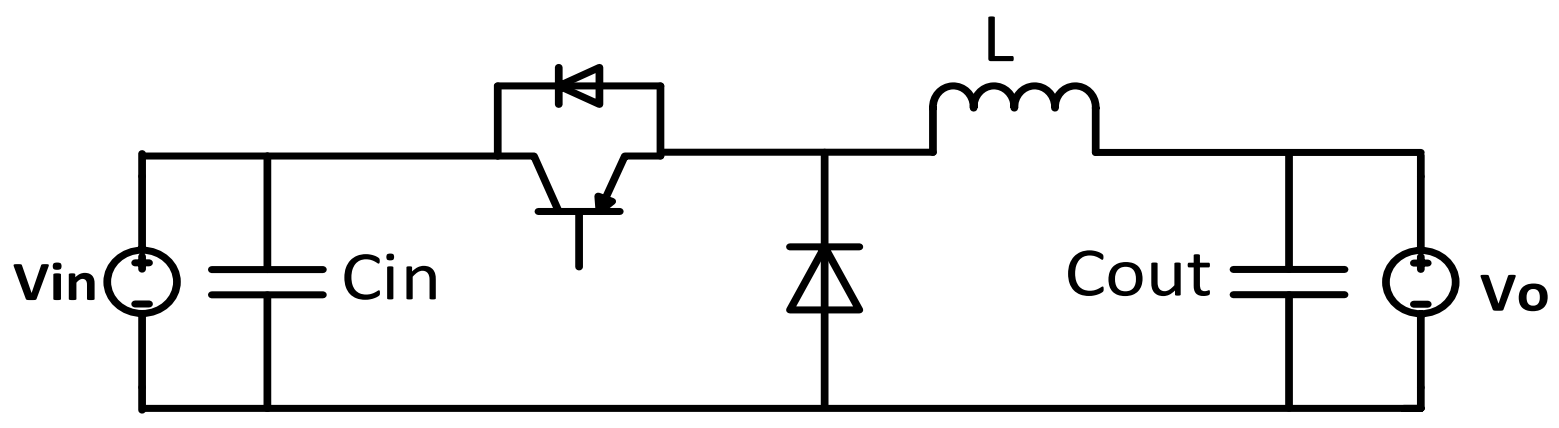

Fig.4. DC-DC buck converter

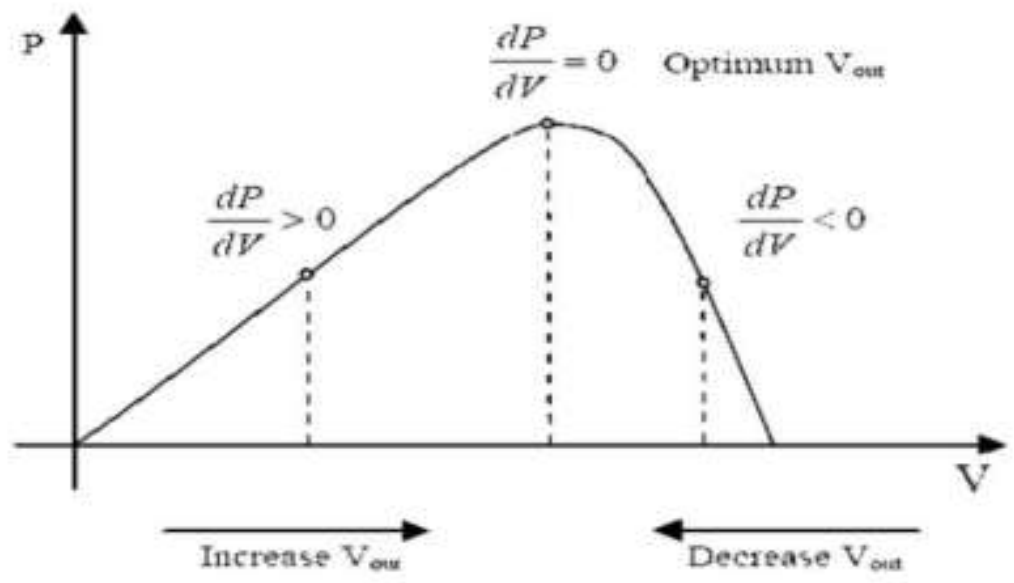

Fig.5. Perturb and observe method

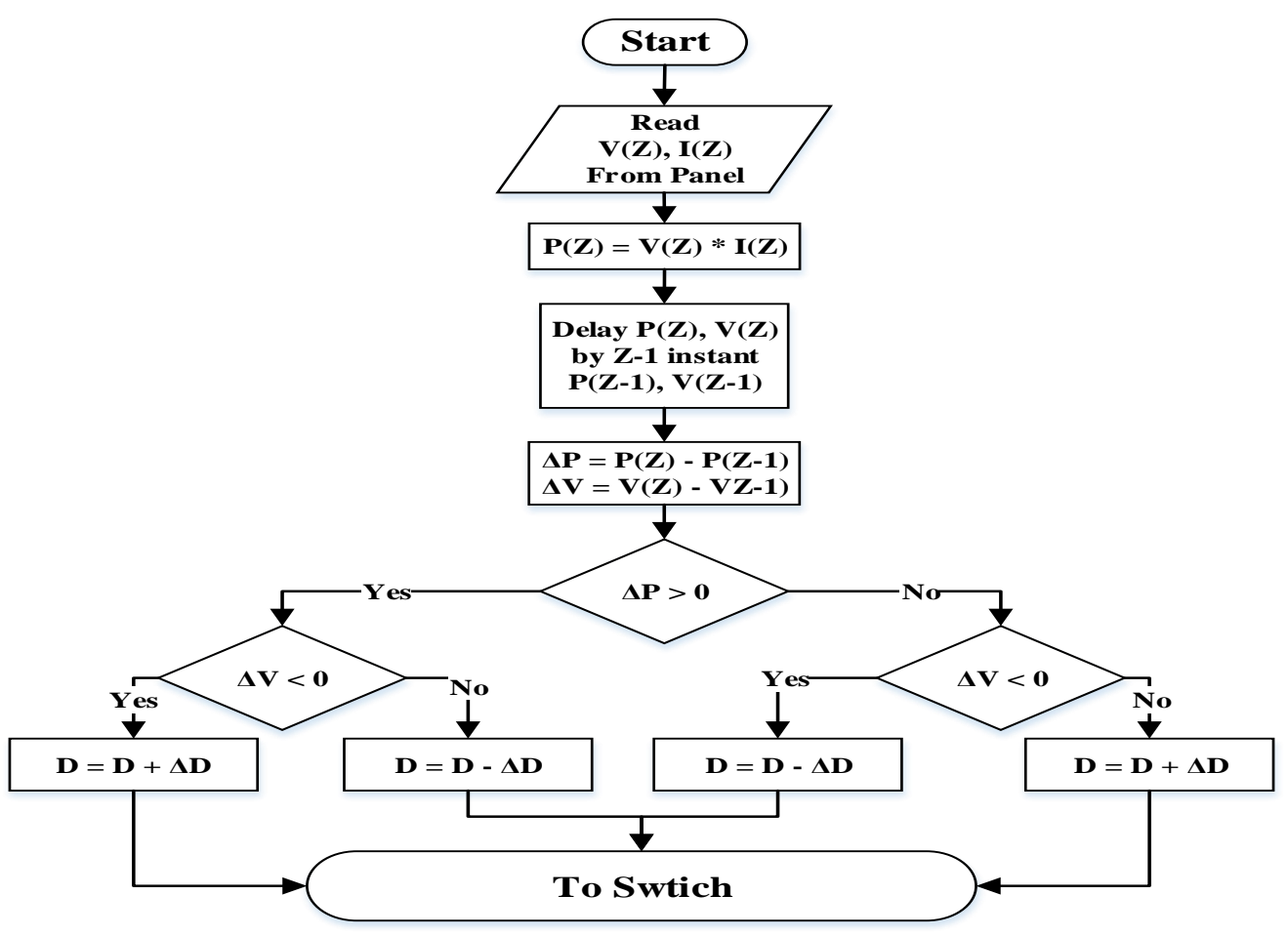

Fig.6. Perturb and observe method flow chart 


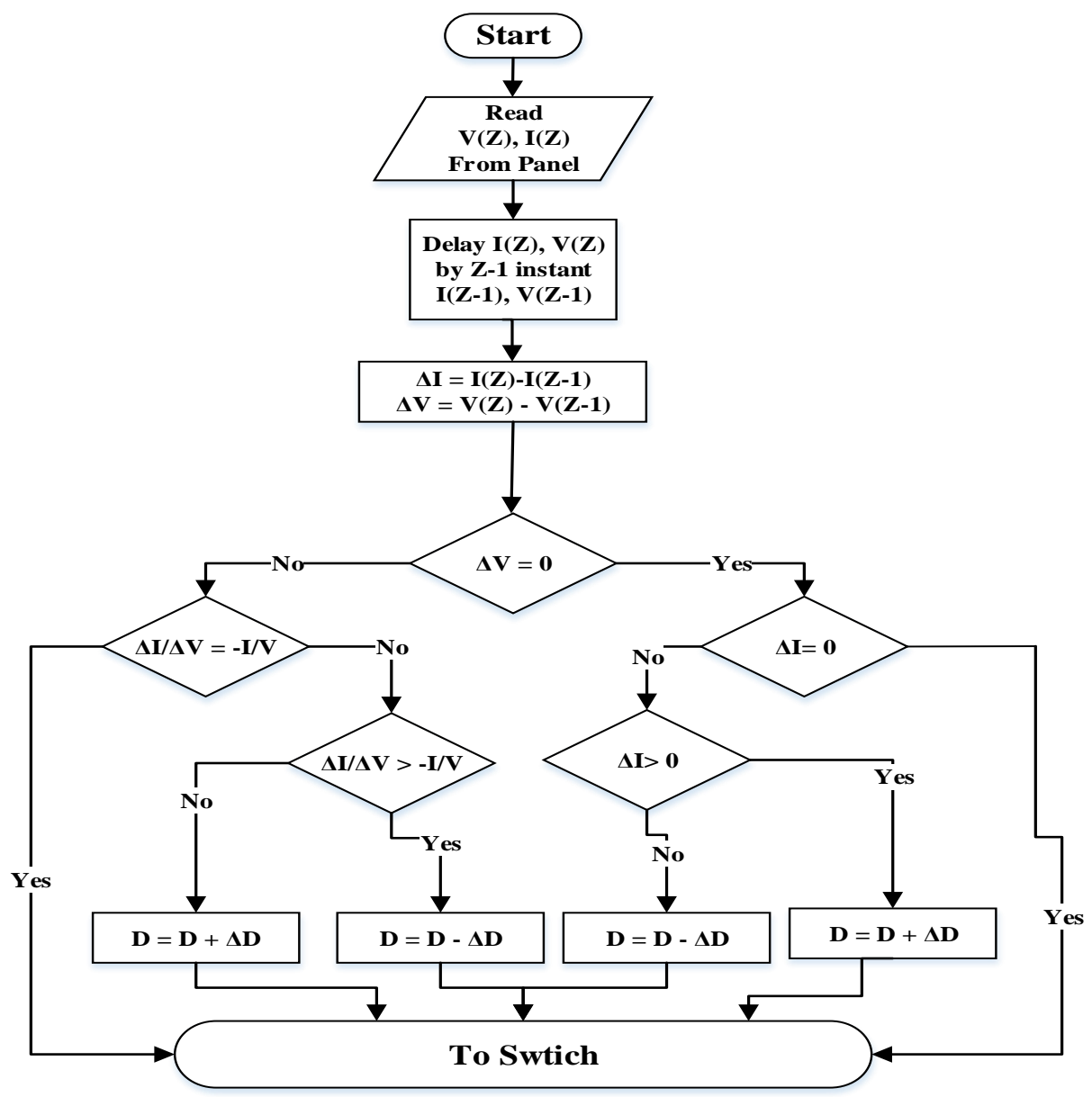

Fig.7. Incremental conductance method (INC) flow chart

Table 1. PV module specifications.

\begin{tabular}{|l|l|}
\hline Electrical characteristics & $\begin{array}{l}\text { Mono crystalline } \\
\text { TS-S410 }\end{array}$ \\
\hline Open-Circuit Voltage & $60.32 \mathrm{~V}$ \\
\hline Short-Circuit Current & $8.95 \mathrm{~A}$ \\
\hline Maximum Power Voltage & $48.41 \mathrm{~V}$ \\
\hline Maximum Power Current & $8.47 \mathrm{~A}$ \\
\hline Maximum Power & $410 \mathrm{~W}$ \\
\hline Temperature Coefficient of ISC & $0.01 \% /{ }^{\circ} \mathrm{C}$ \\
\hline Temperature Coefficient of VOC & $-0.36 \% /{ }^{\circ} \mathrm{C}$ \\
\hline Temperature Coefficient of $\mathrm{Pm}$ & $-0.47 \% /{ }^{\circ} \mathrm{C}$ \\
\hline
\end{tabular}


Table 2. Average production through one day in a year

\begin{tabular}{|c|c|c|c|}
\hline Month & $\begin{array}{c}\text { Average peak Sun } \\
\text { hours (hrs) }\end{array}$ & $\begin{array}{c}\text { Output power } \\
\text { (Kw) }\end{array}$ & $\begin{array}{c}\text { Output energy } \\
\text { (kwhr/day) }\end{array}$ \\
\hline $12 / 2016$ & 5.73 & 25.6 & 146.7 \\
\hline $1 / 2017$ & 5.8 & 23.9 & 138.7 \\
\hline $2 / 2017$ & 6.38 & 25.5 & 162.6 \\
\hline $3 / 2017$ & 6.44 & 23.1 & 148.7 \\
\hline $4 / 2017$ & 6.18 & 24.1 & 148.7 \\
\hline $5 / 2017$ & 5.63 & 23.6 & 132.7 \\
\hline $6 / 2017$ & 5.92 & 18.4 & 109.2 \\
\hline $7 / 2017$ & 5.51 & 29.1 & 160.2 \\
\hline $8 / 2017$ & 6.32 & 26 & 164.2 \\
\hline $9 / 2017$ & 6.89 & 22.1 & 152.3 \\
\hline $10 / 2017$ & 6.2 & 30.4 & 188.3 \\
\hline $11 / 2017$ & 6.37 & 28.3 & 180.4 \\
\hline
\end{tabular}

Table 3. Design of UEEDC converter topology

\begin{tabular}{|c|c|c|c|}
\hline \multicolumn{2}{|c|}{ Parameter } & Symbol & Value \\
\hline \multicolumn{2}{|c|}{ Power (2 strings) } & $P_{\text {in }}$ & $11.48 \mathrm{~kW}$ \\
\hline \multicolumn{2}{|c|}{ Power (3 strings) } & $P_{\text {in }}$ & $17.22 \mathrm{~kW}$ \\
\hline \multicolumn{2}{|c|}{ Input Voltage } & $V_{\text {in }}$ & $700 \mathrm{~V}$ \\
\hline \multicolumn{2}{|c|}{ Output Voltage } & $V_{0}$ & $400 \mathrm{~V}$ \\
\hline \multicolumn{2}{|c|}{ Switching Frequency } & $f_{s w}$ & $30 \mathrm{kHz}$ \\
\hline \multicolumn{2}{|c|}{ Inductor Current Ripple Ratio } & $\Delta \mathrm{i} \mathrm{L}$ & 0.1 \\
\hline \multicolumn{2}{|c|}{ Capacitor Voltage Ripple Ratio } & $\Delta \mathrm{V}_{\mathrm{C}}$ & 0.04 \\
\hline \multicolumn{2}{|c|}{ Duty Cycle } & $\mathrm{D}$ & 0.5 \\
\hline \multirow{2}{*}{2 strings } & Input Inductance & $\mathrm{L}$ & $2 \mathrm{mH}$ \\
\hline & Output capacitor & C & $0.75 \mu \mathrm{F}$ \\
\hline \multirow{2}{*}{3 strings } & Input Inductance & $\mathrm{L}$ & $1.33 \mathrm{mH}$ \\
\hline & Output capacitor & $\mathrm{C}$ & $1.121 \mu \mathrm{F}$ \\
\hline
\end{tabular}

Table 4. Conclusion of perturb and observation (P\&O) MPPT method

\begin{tabular}{|c|c|c|}
\hline Change in voltage & Change in Power & Change in duty cycle \\
\hline Positive & Positive & Negative \\
\hline Negative & Positive & Positive \\
\hline Positive & Negative & Positive \\
\hline Negative & Negative & Negative \\
\hline
\end{tabular}

Table 5. The average output power value and efficiency of normal PV power station operation for $1000 \mathrm{~W} / \mathrm{m}^{2}, 800 \mathrm{~W} / \mathrm{m}^{2}, 500 \mathrm{~W} / \mathrm{m}^{2}$ and $300 \mathrm{~W} / \mathrm{m}^{2}$ irradiances with two methods 


\begin{tabular}{|c|c|c|c|c|c|}
\hline \multirow[b]{2}{*}{$\begin{array}{l}\text { Irradiance } \\
\text { (W/m2) }\end{array}$} & \multirow{2}{*}{$\begin{array}{l}\text { Theoretical } \\
\text { PV Power } \\
\text { station } \\
\text { UEEDC } \\
\text { (kW) }\end{array}$} & \multicolumn{2}{|c|}{$\begin{array}{c}\text { Simulation (PSIM) } \\
\text { software } \\
(k W)\end{array}$} & \multirow[b]{2}{*}{$\begin{array}{c}\text { efficiency } \\
\text { of (P\&O) } \\
\text { algorithm } \\
(\%)\end{array}$} & \multirow[b]{2}{*}{$\begin{array}{l}\text { efficiency } \\
\text { of (INC) } \\
\text { algorithm } \\
(\%)\end{array}$} \\
\hline & & $\begin{array}{c}\text { Perturb } \\
\text { and } \\
\text { Observe } \\
\text { (P\&O) } \\
\text { method }\end{array}$ & $\begin{array}{c}\text { incremental } \\
\text { conductance } \\
\text { (INC) } \\
\text { method }\end{array}$ & & \\
\hline 1000 & 40.180 & 37.77 & 38.19 & 94 & 95.05 \\
\hline 800 & 32.14 & 30.70 & 30.94 & 95.52 & 96.27 \\
\hline 500 & 20.09 & 19.45 & 19.59 & 96.81 & 97.51 \\
\hline 300 & 12.05 & 11.61 & 11.65 & 96.35 & 96.68 \\
\hline
\end{tabular}

Power (w)

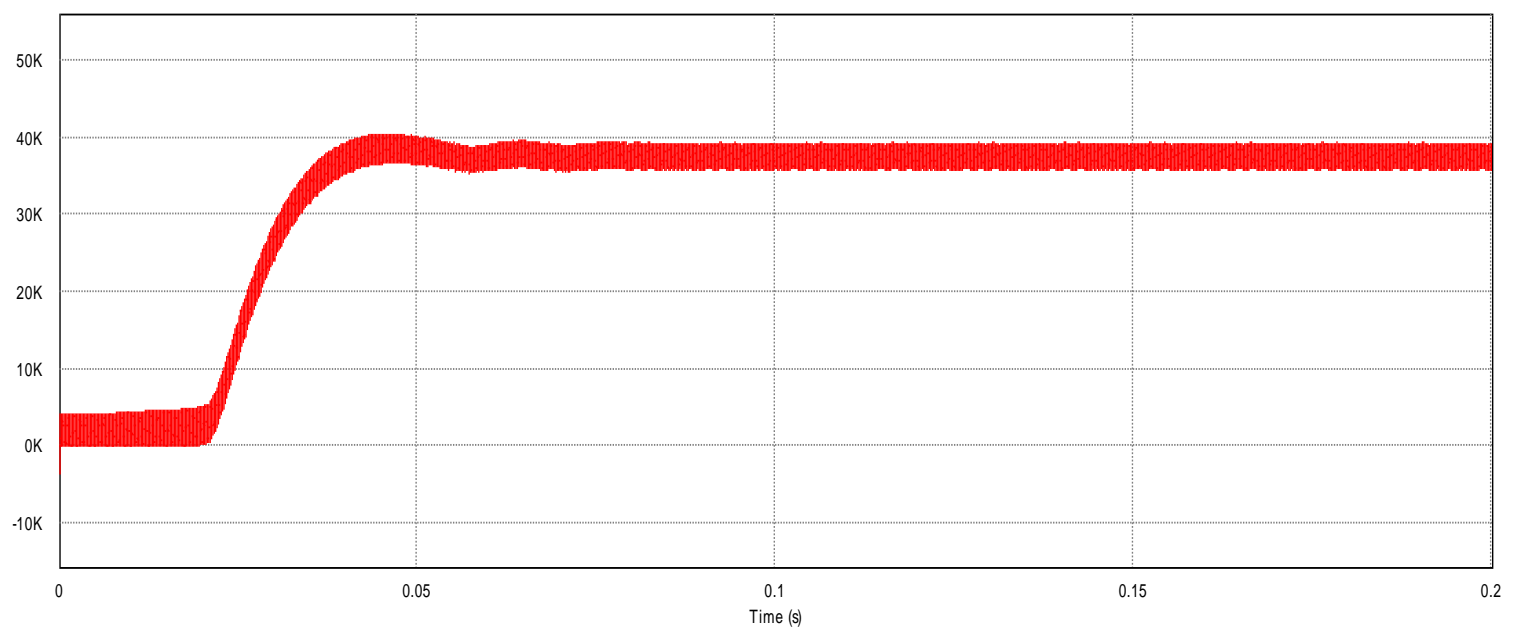

(a)

Power (w)

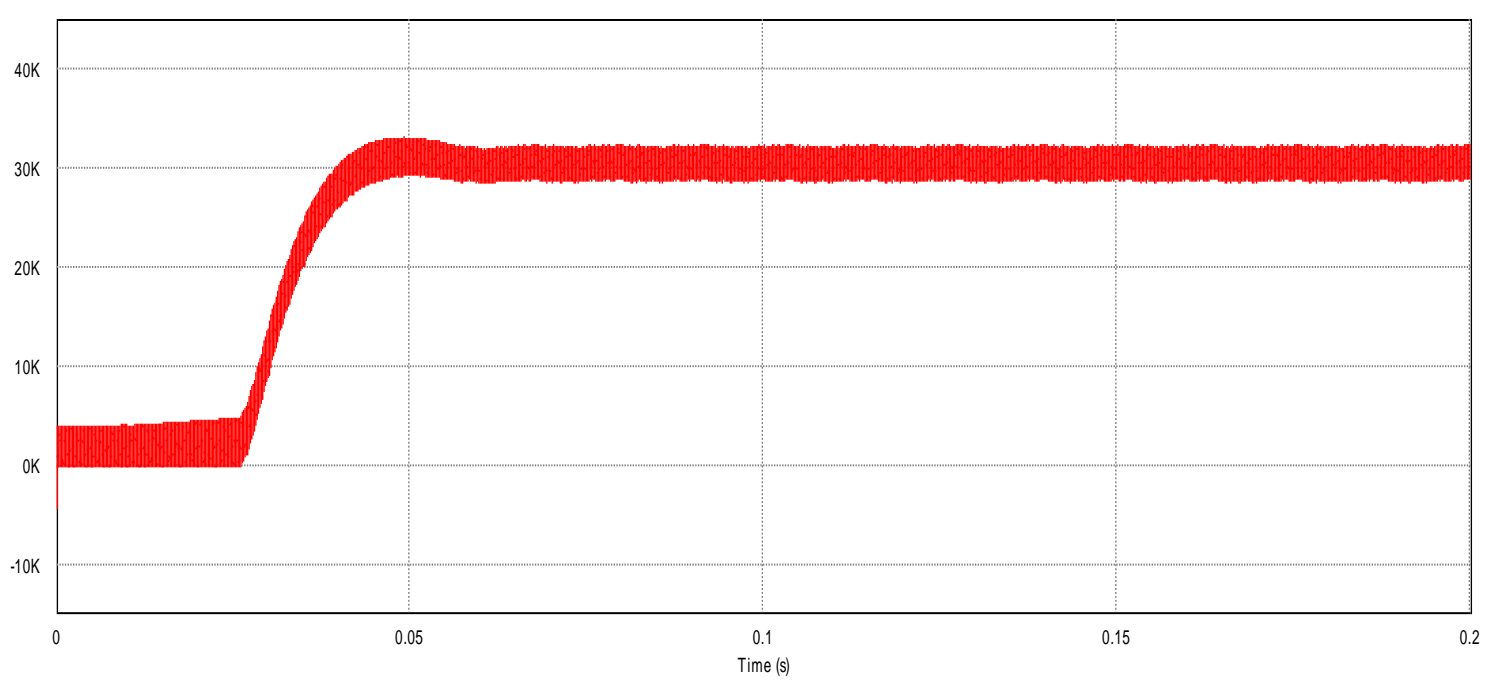

(b) 
Power (w)

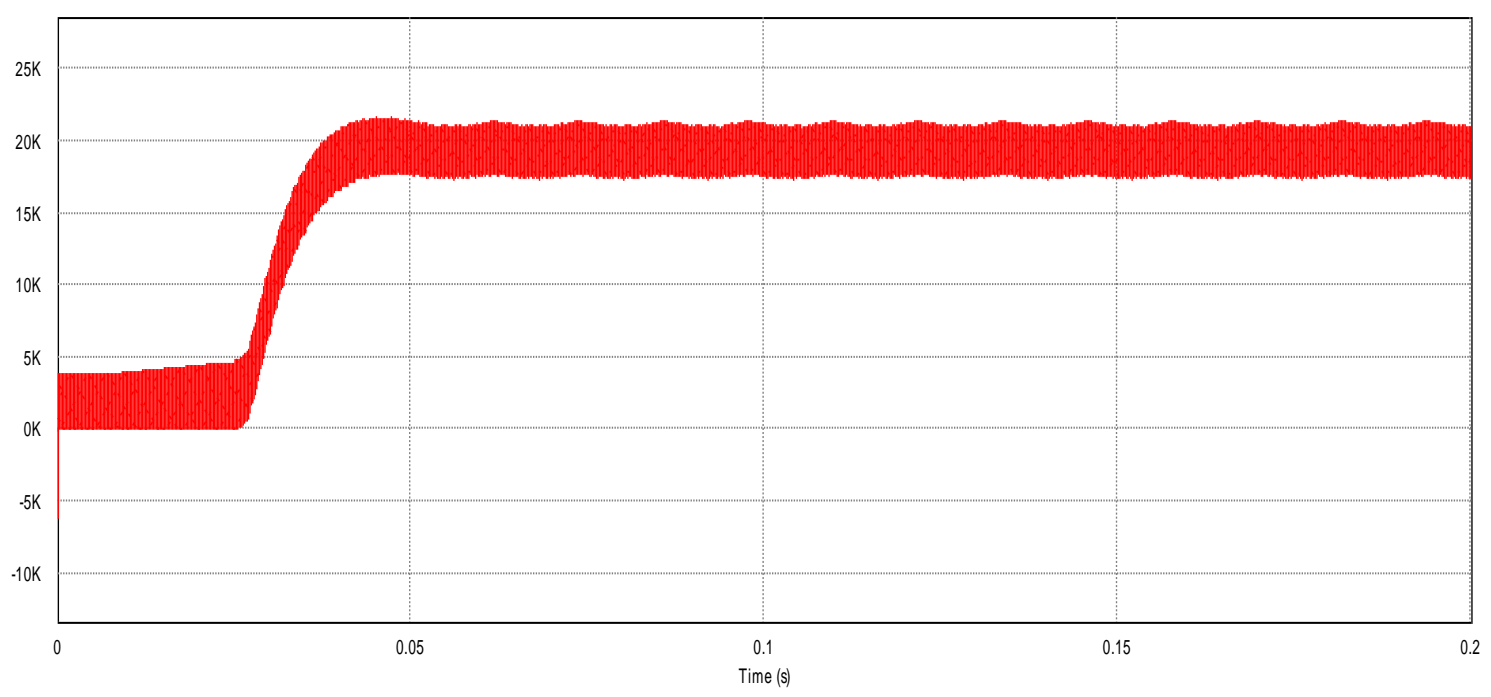

(c)

Power (w)

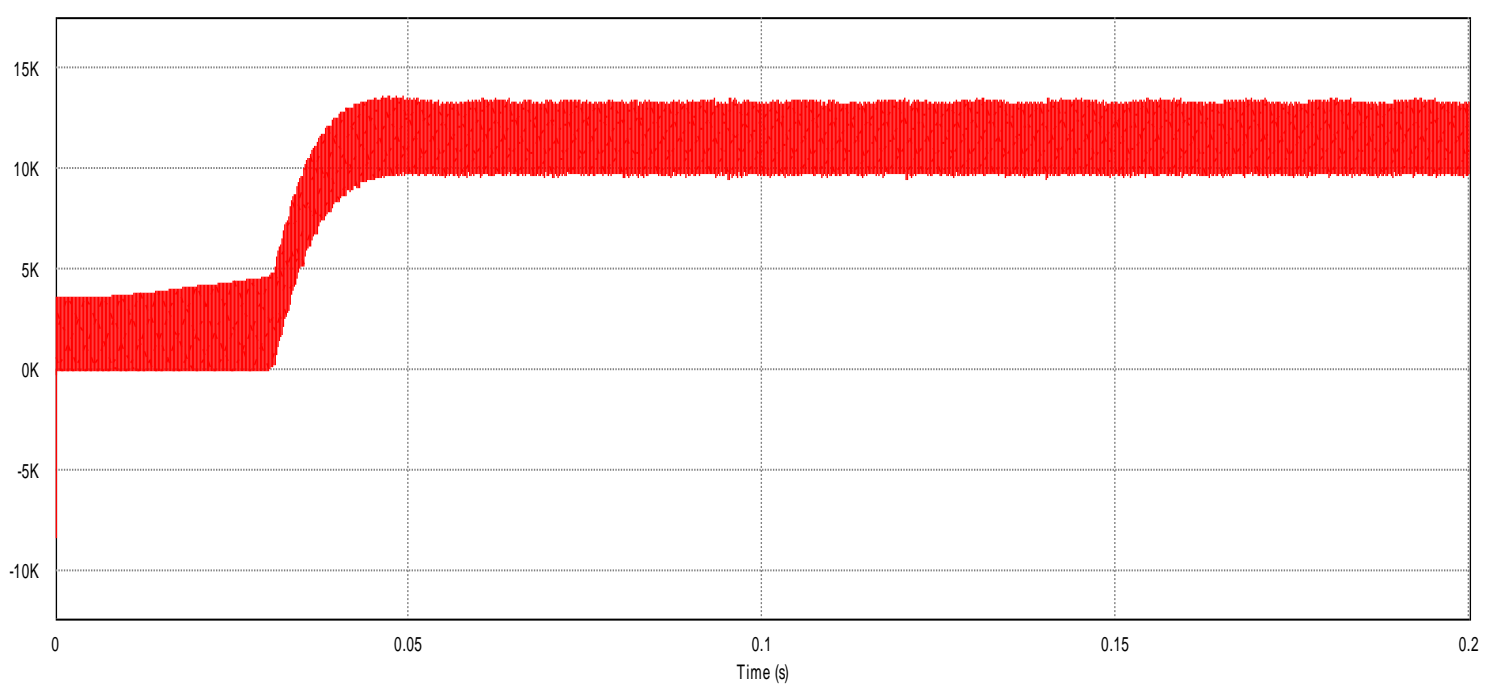

(d)

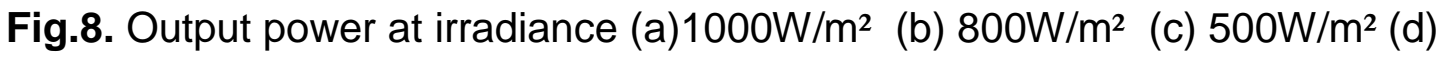
$300 \mathrm{~W} / \mathrm{m}^{2}$ with perturb and observe (P\&O) method. 
Power (w)

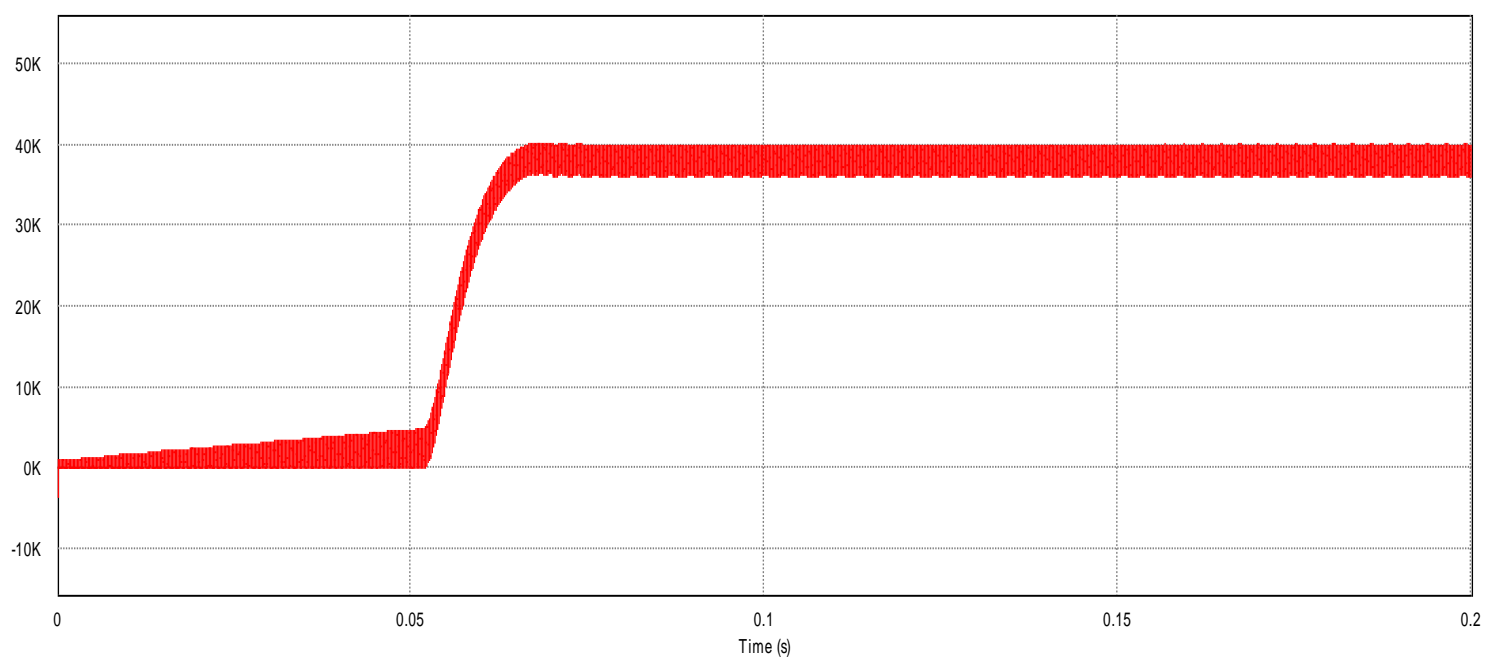

(a)

Power (w)

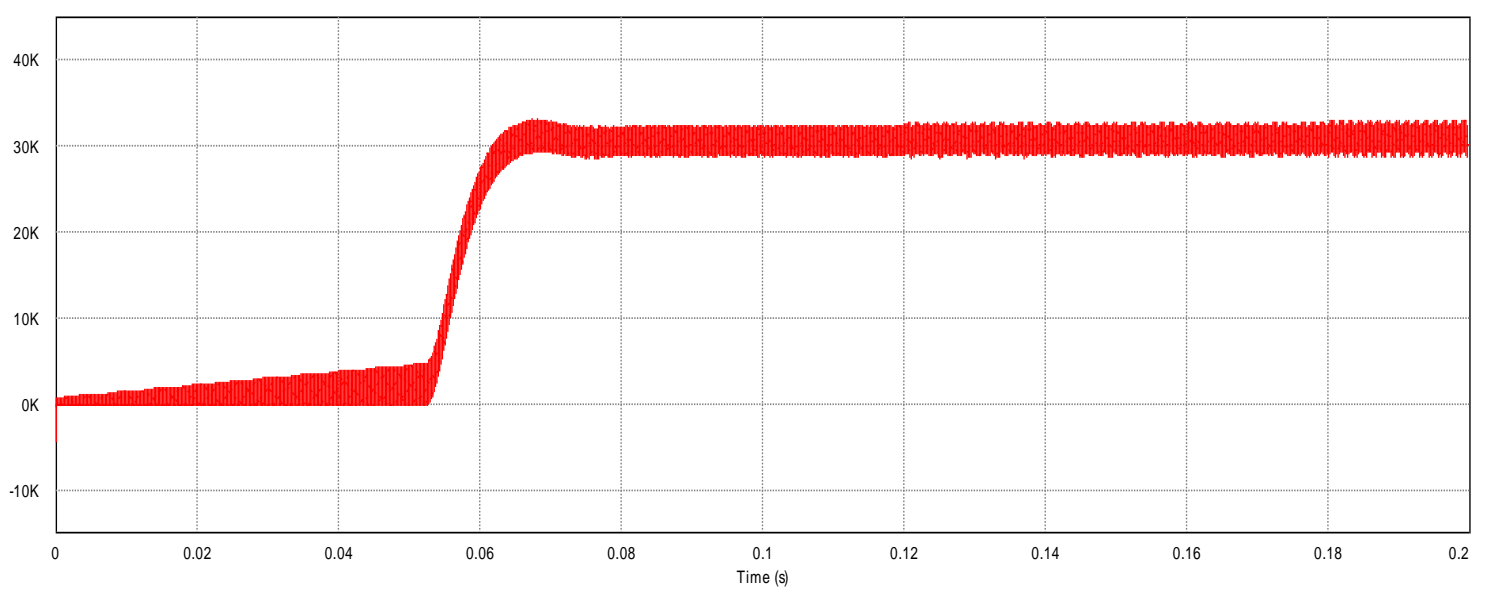

(b)

Power (w)

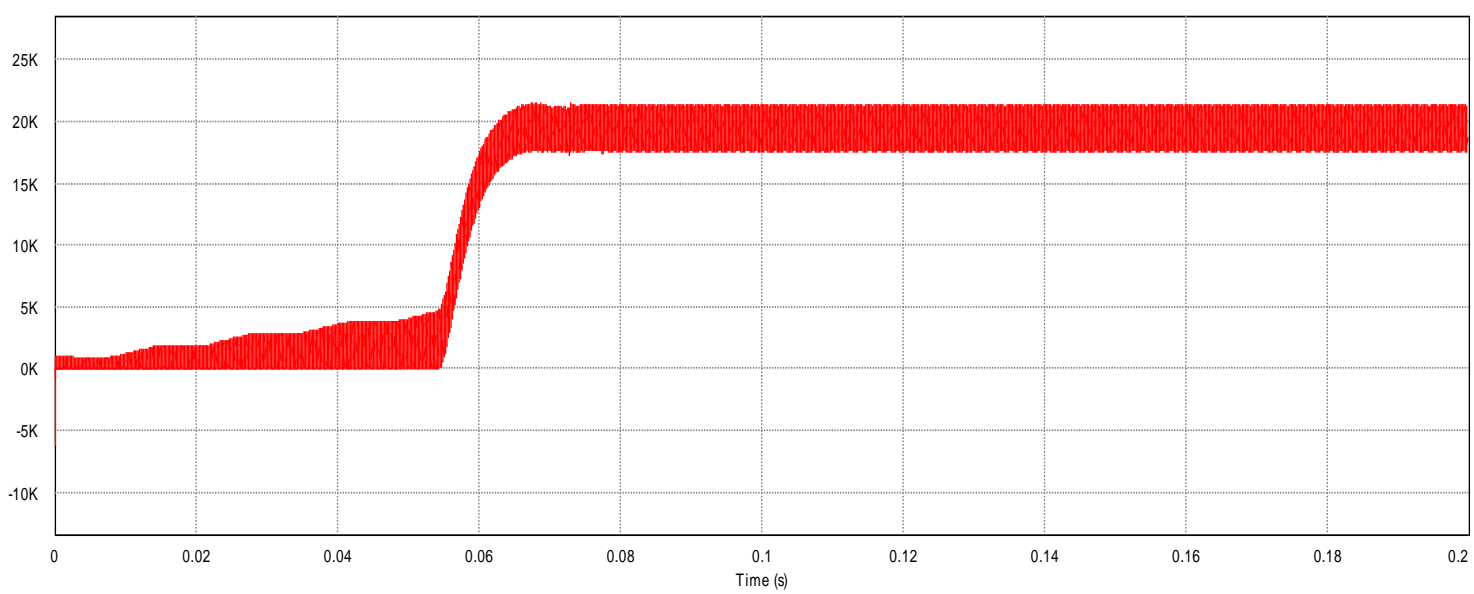

(c) 
Power (w)

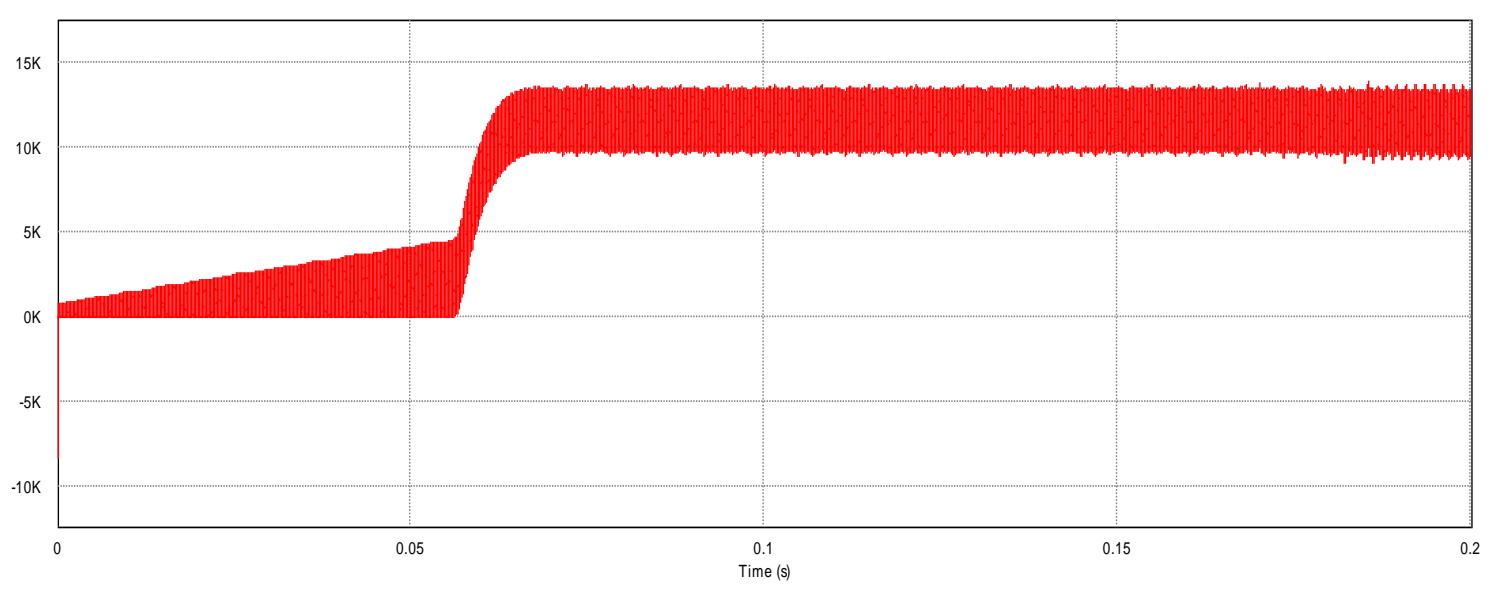

(d)

Fig.9. Output power at irradiance (a) $1000 \mathrm{~W} / \mathrm{m}^{2}$ (b) $800 \mathrm{~W} / \mathrm{m}^{2}$ (c) $500 \mathrm{~W} / \mathrm{m}^{2}$ (d) $300 \mathrm{~W} / \mathrm{m}^{2}$ with incremental conductance (INC) method. 